\title{
Phenotypic Characterization of the Response to Infection with Trichinella spiralis in Genetically Defined Mouse Lines of the CBi-IGE Stock
}

\author{
María D. Vasconi'1,2, Griselda Bertorini'2, Ana V. Codina1', Paula Indelman², \\ Ricardo J. Di Masso',3, Lucila I. Hinrichsen ${ }^{1,3^{*}}$ \\ ${ }^{1}$ Instituto de Genética Experimental, Facultad de Ciencias Médicas, Universidad Nacional de Rosario, Rosario, \\ Argentina \\ 22Área Parasitología, Facultad de Ciencias Bioquímicas y Farmacéuticas, Universidad Nacional de Rosario, \\ Rosario, Argentina \\ ${ }^{3} \mathrm{CIC}$-UNR, Universidad Nacional de Rosario, Rosario, Argentina \\ Email: ${ }^{*}$ hinrich@unr.edu.ar
}

Received 1 April 2015; accepted 17 May 2015; published 20 May 2015

Copyright @ 2015 by authors and Scientific Research Publishing Inc.

This work is licensed under the Creative Commons Attribution International License (CC BY).

http://creativecommons.org/licenses/by/4.0/

(c) (i) Open Access

\section{Abstract}

Trichinella spiralis (T. spiralis), which is a cosmopolitan nematode that infects humans among other species, presents a complex host-parasite relationship that hinders the development of tools to eradicate the parasitosis. The aim of this research was to analyze the host response during a primary infection with $T$. spiralis in five genetically different mouse lines of the CBi-IGE stock. Adult males from the $\mathrm{CBi}+, \mathrm{CBi}-, \mathrm{CBi}, \mathrm{CBi} / \mathrm{L}$ and $\mathrm{CBi} / \mathrm{C}$ lines were infected with 1,2 or $4 \mathrm{L1}$ larvae per $\mathrm{g}$ of body weight. In the chronic stage, the number of parasites per $\mathrm{g}$ of tissue (relative larval load, rLL) showed a significant host genotype-dose interaction, since it did not increase in the same way in the five genotypes. At the lowest dose, both $\mathrm{CBi}$ - and $\mathrm{CBi} / \mathrm{L}$ mice were resistant while $\mathrm{CBi}+, \mathrm{CBi} / \mathrm{C}$, and $\mathrm{CBi}$ were susceptible. At the highest dose, only $\mathrm{CBi} / \mathrm{L}$ remained resistant, and $\mathrm{CBi}+$ was the most susceptible. The reproductive capacity index of adult worms $(\mathrm{RCI}=\mathrm{rLL} / \mathrm{infective}$ dose $)$ evinced only a genotype effect, allowing rating each line as resistant or susceptible regardless of dose. Animals receiving $2 \mathrm{L1}$ larvae were also sacrificed in the intestinal phase (6 and 13 days p-i) to determine the number of adult parasites (nAP) recovered in a small intestine segment, and female fecundity (Ff). No differences in nAP were observed among genotypes on day 6 p-i. nAP decreased between days 6 and $13 p-i$, this reduction being different among genotypes and significant only in $\mathrm{CBi} / \mathrm{L}$ and $\mathrm{CBi} / \mathrm{C}$. Ff decreased in $\mathrm{CBi} / \mathrm{L}$ and $\mathrm{CBi} / \mathrm{C}$ on day $13 \mathrm{p}$-i. At the time of infection, serum cytokine baseline values showed a Th1 orientation for genotype CBi/L (high IFN- $\gamma$ and IL-2)

*Corresponding author.

How to cite this paper: Vasconi, M.D., Bertorini, G., Codina, A.V., Indelman, P., Di Masso, R.J. and Hinrichsen, L.I. (2015) Phenotypic Characterization of the Response to Infection with Trichinella spiralis in Genetically Defined Mouse Lines of the CBi-IGE Stock. Open Journal of Veterinary Medicine, 5, 111-122. http://dx.doi.org/10.4236/ojvm.2015.55015 
and a Th2 for CBi+ (high IL-4 and IL-10).The variability in the response observed in this murine model suggests its potential usefulness to gain insight into the mechanisms that regulate hostparasite relationship.

\title{
Keywords
}

\author{
Host Genotype-Parasite Relationship, Gastrointestinal Nematode, Trichinella spiralis, Infectivity, \\ Resistance
}

\section{Introduction}

Trichinella spiralis, a nematode parasite that infests humans and a wide range of carnivorous and omnivorous mammals, is an important foodborne pathogen causing considerable morbidity and mortality. The resulting disease, trichinellosis, is a major zoonosis in Latin America. In Argentina, it is considered as an endemic disease with epidemic outbreaks and is included within food notifiable diseases [1]. Despite the significant technical and medical advances to control trichinellosis, the prospect of its eradication remains frustrating due, in part, to the complex and durable relationship between parasite and host, whose essential feature is chronicity. Trichinella spiralis is characterized by lack of host specificity, different structural forms within the same host and different ecological niches during its cycle [2]. Ingested muscle larvae escape from their cysts due to the acidity of the stomach and migrate to the small intestine. In the intestinal mucosa, they mature into adults and mate, releasing newborn larvae from a four-day post-infection. These newborn larvae migrate into the lymphatic and blood vessels entering various organs such as the retina, myocardium, lung, or lymph nodes as well as muscle. However, only larvae that penetrate skeletal muscle cells may survive and develop to the infective muscle-stage larvae (L1 infective larvae) without molting. There, they create a protective structure (nurse cell) within which the parasite grows and survives, reaching its full size within a month. Thus, Trichinella spiralis establishes chronic infections in skeletal muscles of immunocompetent hosts. This muscle infection is crucial to transmission and survival of the parasite in nature.

As prevention is a key strategy for controlling this parasitosis, measures should be implemented to reduce the number of mammals capable of becoming infected with the parasite. Some of these measures should be based on an understanding of the intimate mechanisms that regulate host-parasite relationship. Susceptibility to parasitic infections results from a complex equation that includes the interactions among the environment, the genotype of the host and the parasite genotype. With this assertion in mind, it is self-evident that the genotype of the host plays a significant role in the establishment of the infection. In this sense, murine models of intestinal nematode infection have proved to be relevant and tractable systems to define the cellular and molecular basis of how the host defense system regulates resistance and susceptibility to infection [3]. Although the immune response of the host limits parasitic aggression, it does not usually achieve complete removal of the parasite. Therefore, to further understand and characterize this complex host-parasite relationship, new experimental models need to be explored. The Institute of Experimental Genetics mouse colony includes five genetically distinct lines (CBi-IGE stock: $\mathrm{CBi}+, \mathrm{CBi}^{-}, \mathrm{CBi} / \mathrm{L}, \mathrm{CBi} / \mathrm{C}$ and $\mathrm{CBi}$ ). It has been demonstrated that these lines respond differently to experimental infection with Heligmosomoides polygyrus and Trypanosoma cruzi [4], so they are a unique resource for dissecting the genetic basis underlying line divergence as well for elucidating genes causing the variation in response to infection with parasites in wild rodent populations and in other species, including humans. Genetically defined animals are valuable models to evaluate the resistance/susceptibility to infection in the course of the disease. The identification of the characteristics of the risk genotypes and those that express resistance to the parasite will allow implementing policies of early intervention to decrease the reservoirs of the infecting agent in mammals, thereby reducing human risk at both the individual and population levels.

Mammalian host resistance to infection by parasites is under genetic control at many different levels: among species, among races, breeds and lines of single species and among individuals [5]. These genetic effects have been demonstrated in several host-parasite systems. This study investigates the interaction between two variables: host genotype and magnitude of the infective dose on Trichinella spiralis infection in CBi-IGE mice lines with different susceptibility to natural as well to experimental parasite infections [4]. Moreover, this study 
examines the effect of the host genotype during a primary infection with Trichinella spiralis at different stages of the parasite life cycle as well as the relationship between the Th1/Th2 serum cytokine profile of each line prior to infection and its resistance/susceptibility to the parasite.

\section{Materials and Methods}

\subsection{Animals}

Adult male mice (90 to 110 days of age) from five lines $\left(\mathrm{CBi}+, \mathrm{CBi}^{-}, \mathrm{CBi} / \mathrm{C}, \mathrm{CBi} / \mathrm{L}\right.$ and $\mathrm{CBi}$ ) of the $\mathrm{CBi}$ stock from the Animal Facilities of the Instituto de Genética Experimental, Facultad de Ciencias Médicas, Universidad Nacional de Rosario (from here on, CBi/IGE stock) were used. Four of the lines were selected by means of a biological quantitative index combining body weight and tail length at 49 days of age. A detailed description of the selective procedure is given elsewhere [6] [7]. Briefly, two lines were selected according to the positive genetic correlation between both traits (agonistic selection: $\mathrm{CBi}+$, high body weight-long tail; $\mathrm{CBi}^{-}$, low body weight-short tail) and the other two were obtained by selecting against the aforementioned correlation (antagonistic selection: $\mathrm{CBi} / \mathrm{C}$, high body weight-short tail; $\mathrm{CBi} / \mathrm{L}$, low body weight-long tail). Mice belonging to the $\mathrm{CBi}$ line (non-selected) were used as control of selection. The lines are currently in their 120th generation of selective breeding, and their theoretical inbreeding coefficient is 0.99 . The facilities belong to the conventional, semi-open type. Young adults from both sexes of each line were housed, separated by sex since weaning, in polypropylene cages $(32 \times 24 \times 10 \mathrm{~cm})$ with wood shavings for bedding, in a room with constant temperature $\left(23^{\circ} \mathrm{C} \pm 3^{\circ} \mathrm{C}\right)$, relative humidity of $50 \% \pm 10 \%$ and light-dark illumination cycle of $12 \mathrm{~h}$. Cages and bedding were changed twice weekly. Tap water and food (Cargill Laboratory Chow, pelletized) were provided ad libitum. All the experiments with mice were done during the first half of the light cycle and according to animal care standards of the institution, which complies with guidelines established by the Institute for Laboratory Animal Resources [8]. Animals were euthanized by inhalation of CO2. All experimental protocols were approved by the IACUC committee at the National University of Rosario School of Medicine (permit number 1384/2012).

\subsection{Study Design}

The effect of host genotype on the evolution of a primary infection with T. spiralis was studied in two phases. First, mice from the five lines were infected p.o. with increasing doses of L1 larvae to corroborate their different susceptibility by analyzing muscle larval load in the chronic stage of the infection. Second, the acute phase of infection was studied using the dose that allowed the maximum expression of the genotypic differences among lines. The number of adult intestinal worms and the female parasite fecundity were determined in this stage.

\subsection{Parasitological Techniques}

\subsubsection{Parasite Maintenance}

T. spiralis was generously provided by Dr. Maria Dalla Fontana (Laboratorio de Zoonosis, Laboratorio Central de la Red Provincial de Laboratorios, Dirección de Bioquímica y Farmacia, Santa Fe, Argentina). It was maintained and passaged in CBi mice since 2006. This strain was typified as Trichinella spiralis using multiplex PCR (Dr. Silvio Krivokapich, Departamento de Parasitología, Administración Nacional de Laboratorios e Institutos de Salud "Dr. Carlos Malbrán", Buenos Aires, Argentina, personal communication). L1 infective larvae used in the infection were recovered by artificial digestion [9], from the muscles of a CBi mouse infected 2 3 months earlier for that purpose. Briefly, the infected mouse was euthanized, decapitated, skinned and eviscerated, and its carcass without tail and limbs was minced with a standard kitchen blender; the tongue was excised and included in this step. The blender content was poured in a beaker and digested at $37^{\circ} \mathrm{C}$ in a $1 \% \mathrm{w} / \mathrm{v}$ pep$\sin -0.1 \mathrm{~N} \mathrm{HCl}$ solution. At the end of the incubation period, larvae were collected by pouring the digestion fluid through a mesh, washed several times in saline and suspended in PBS. From this suspension, the exact dose for each animal was prepared.

\subsubsection{Challenge Infection}

Mice were infected orally with a single dose of 1, 2 or 4 T. spiralis $\mathrm{L} 1$ infective larvae per $\mathrm{g}$ of body weight $(\mathrm{n}=$ 10 per line and dose). The choice of this dose range was based on different bibliographic data [10]-[13] and was 
aimed to detect potential differences among genotypes. Since the lines show significant differences in body weight, the equivalent dose for each mouse was calculated as the number of infective larvae per $g$ of body weight of each particular host. The behavior of the lines against the parasite was evaluated through different variables in the acute (enteric) and chronic (parenteral) phase of infection. During the course of the experience, the animals were weighed twice weekly to determine whether infection altered the normal variations in body weight, and their physical condition was monitored for signs and symptoms of trichinellosis.

\subsection{Analysis of the Parenteral Stage of the Infection}

Larval load was assessed on the chronic phase of the infection ( $40 \pm 2$ days post-infection, p-i), by counting the number of muscle encysted larvae (muscle larval load) in the tongue of each animal. The tongue was chosen because it is a preferred site of encystment in mice [9] and sampling of such sites provides the best chance of recovering $T$. spiralis larvae in low-level infections [14]. Briefly, after euthanizing the mouse the tongue was excised, weighed to the nearest milligram and submitted to digestion in $2 \mathrm{~mL}$ of digestion fluid (pepsin 1:1000, $0.7 \mathrm{~g}$; HCl, $0.9 \mathrm{~g}$; water, up to $100 \mathrm{~mL}$ ). The mixture was incubated at $37^{\circ} \mathrm{C}$ overnight and stirred periodically at moderate speed. At the end of the incubation period, digestion was stopped by adding saline to complete $14 \mathrm{~mL}$, and larvae were allowed to decant for $1 \mathrm{~h}$. The supernatant was removed immediately and, in order to inactivate the larvae and preserve their structure, $5 \mathrm{~mL}$ of $10 \% \mathrm{v} / \mathrm{v}$ buffered formalin were admixed. Finally, all larvae from each sample were transferred to a gridded acrylic plate and counted under a microscope with a 40X magnification. Larval load was calculated as the total number of larvae per g of muscle tissue (relative larval load, rLL). The index of reproductive capacity (RCI) was calculated for each mouse as rLL/dose [12] [15] [16].

\subsection{Analysis of the Enteral Phase of the Infection}

Mice given an oral dose of $2 \mathrm{~L} 1$ larvae per g body weight were sacrificed in the intestinal phase of the infection ( 6 and 13 days $p-i)(n=12$ per line and time point). As described by Luebke [9], the effective adaptive response of the host to limit parasite infectivity was assessed by determining the number of intestinal adult parasites, to evaluate the host ability to expel worms. Briefly, animals were euthanized, and the first third of the small intestine (approximately $20 \mathrm{~cm}$ long) was removed, cut into two pieces of roughly equal length and placed on two Petri dishes with $8-12 \mathrm{~mL}$ of $0.85 \% \mathrm{NaCl}$ plus $250 \mu \mathrm{g} / \mathrm{mL}$ gentamicin (incubation medium). Each piece was then opened lengthwise using a small iris scissors, grasped with forceps, agitated briefly in the medium, and incubated for $4 \mathrm{~h}$ at $37^{\circ} \mathrm{C}$ in $5 \% \mathrm{CO}_{2}$. After incubation, the pieces of intestine were rinsed with the medium onto the Petri dish and discarded. All the content of both Petri dishes was transferred to centrifuge tubes and centrifuged at low speed. The parasite pellet was re-suspended in approximately $1 \mathrm{~mL}$ medium and placed in a gridded acrylic plate, to count adult worms. Adults were counted with a microscope at $40 \mathrm{X}$ magnification, and the result was expressed as the total number of adult parasites in the small intestine segment analyzed (nAP). The relative number of intestinal parasites (rnAP) was computed for each animal as nAP/infective dose. Then, female parasite fecundity, an indicator of the host influence on the reproductive capacity of $T$. spiralis females, was also measured. The female worms in the acrylic plate were identified, isolated (up to 10 from each mouse), rinsed with the incubation medium and transferred to separate wells of a 96 well tissue culture plate containing RPMI 1640 media supplemented with $10 \%$ fetal calf serum plus $250 \mu \mathrm{g} / \mathrm{mL}$ gentamicin [9]. Plates were incubated for $18 \mathrm{~h}$ at $37^{\circ} \mathrm{C}$ in $5 \% \mathrm{CO}_{2}$, and newborn larvae were counted using a microscope at $100 \mathrm{X}$ magnification. Results were expressed as the average number of newborn larvae per female parasite (Ff).

\subsection{Serum Interleukin Determination}

The serum levels of Th1 (INF- $\gamma$ and IL-2) and Th2 (IL-4 and IL-10) cytokines were studied in normal, non-parasitized mice ( $\mathrm{n}=7$ per line), treated 5 days before blood sampling with fenbendazole (baseline values). Blood was taken by cardiac puncture and, after clot retraction by incubation at $37^{\circ} \mathrm{C}$, the serum was collected from each sample, aliquoted in Eppendorf tubes and stored at $-20^{\circ} \mathrm{C}$ until its analysis. Cytokines were determined by ELISA (enzyme-linked immunosorbent assay). A sandwich ELISA using two different antibodies recognizing different epitopes of the cytokines was performedusing a commercial kit (BD OptEIATM, Becton-Dickinson, Argentina) and following the manufacturer's instructions. The results were expressed in $\mathrm{pg} / \mathrm{ml}$. These results correspond to the conditions of naive animals on the day of infection. 


\subsection{Statistical Analysis}

\subsubsection{Univariate Analysis [17]}

The statistical significance of genotype, dose and genotype $\mathrm{x}$ dose effects on relative parasite load and reproductive capacity index were assessed by means of an analysis of variance (ANOVA) corresponding to a $5 \times 3$ factorial design. Comparisons among genotypes within dose or among doses within genotype were done with a one-way ANOVA followed by the Bonferroni post-test. Parasite intestinal burden and T. spiralis female fertility were compared using the Kruskal-Wallis one-way ANOVA by ranks, followed by Dunn post-hoc test or the parametric one-way ANOVA, followed by Bonferroni post-test. Differences between days post-infection in these two variables were analyzed by Mann-Whitney $U$ or Student $t$ tests. The effect of time on the proportion of mice that expelled all worms during the intestinal stage of the parasite cycle was analyzed using Fisher's exact test. In all tests, differences were considered significant if $\mathrm{P}<0.05$.

\subsubsection{Multivariate Analysis}

Serum interleukin data were analyzed with the multivariate technique of principal components (PC) [18]. PC analysis partitions the total phenotypic variation into unrelated linear combinations of direct or inversely correlated fractional values of the original traits allowing to identify patterns not evident when data are statistically treated from a univariate point of view. For statistical analysis purposes, the calculated principal components were treated as new random variables and comparisons among genotypes were done with a one-way ANOVA followed by the Bonferroni post-test.

\section{Results}

Mice neither changed significantly their body weight nor showed signs of impairment in their health status throughout the experiment.

Number of encysted larvae (muscle larval load) provides the ultimate indicator of an effective response to infection and is the result of the cumulative effects of all the responses generated by the host. As shown in Table 1 and Table 2, there was a significant difference in the infection intensity among genotypes $(\mathrm{P}<0.001)$. As expected, the larval load was larger when the infective dose increased $(\mathrm{P}<0.05)$, but the magnitude of this increase was significantly different among genotypes. The interaction genotype-dose (Figure 1(a)) was extremely significant $(\mathrm{P}=0.0002)$. While $\mathrm{CBi} / \mathrm{L}$ and $\mathrm{CBi}-$ mice behaved as resistant at the lowest dose, $\mathrm{CBi}+, \mathrm{CBi}$, and $\mathrm{CBi} / \mathrm{C}$ were susceptible. At the highest dose, only $\mathrm{CBi} / \mathrm{L}$ remained resistant; $\mathrm{CBi}+$ was the most susceptible while $\mathrm{CBi} / \mathrm{C}$, $\mathrm{CBi}$, and $\mathrm{CBi}-$ had an intermediate response. The reproductive capacity index only showed a significant genotype effect (Table 2; Figure 1(b), $\mathrm{P}<0.0001$ ), therefore, this variable allowed to rate each genotype as resistant or susceptible irrespective of the infective dose. Again, $\mathrm{CBi}+$ was classified as the most susceptible genotype and $\mathrm{CBi} / \mathrm{L}$ as the most resistant while the remaining three genotypes presented intermediate behaviors.

The performance of the lines in the intestinal phase of the primary infection is summarized in Table 3. Worm establishment was measured at day six $p-i$ and worm expulsion was assessed at day $13 \mathrm{p}-\mathrm{i}$, determining parasite intestinal burden as the total number of worms (nAP) and the number of worms per infective dose (rnAP) in the

Table 1. Effect of $T$. spiralis increasing infection doses on muscle parasite burden in adult male mice of the CBi-IGE stock $(\mathrm{n}=10$ per group).

\begin{tabular}{|c|c|c|c|c|c|c|c|c|c|c|}
\hline \multirow{2}{*}{$\begin{array}{l}\text { Lines } \\
\text { doses }\end{array}$} & \multicolumn{2}{|c|}{$\mathrm{CBi}^{+}$} & \multicolumn{2}{|c|}{$\mathrm{CBi}^{-}$} & \multicolumn{2}{|c|}{$\mathrm{CBi}$} & \multicolumn{2}{|c|}{$\mathrm{CBi} / \mathrm{L}$} & \multicolumn{2}{|c|}{$\mathrm{CBi} / \mathrm{C}$} \\
\hline & $\begin{array}{l}\text { Body } \\
\text { weight }\end{array}$ & $\mathrm{rLL}^{\#}$ & $\begin{array}{l}\text { Body } \\
\text { weight }\end{array}$ & rLL & $\begin{array}{l}\text { Body } \\
\text { weight }\end{array}$ & rLL & $\begin{array}{l}\text { Body } \\
\text { weight }\end{array}$ & rLL & $\begin{array}{l}\text { Body } \\
\text { weight }\end{array}$ & rLL \\
\hline $\begin{array}{c}\text { Dose I } \\
1 \text { larvae/g BW }\end{array}$ & $\begin{array}{l}51.9 \\
\pm 0.68\end{array}$ & $\begin{array}{l}702^{\mathrm{a}} \\
\pm 139.4\end{array}$ & $\begin{array}{l}28.6 \\
\pm 0.43\end{array}$ & $\begin{array}{c}85^{\mathrm{a}} \\
\pm 24.4\end{array}$ & $\begin{array}{l}38.7 \\
\pm 0.75\end{array}$ & $\begin{array}{l}466^{\mathrm{a}} \\
\pm 98.5\end{array}$ & $\begin{array}{l}31.5 \\
\pm 0.71\end{array}$ & $\begin{array}{c}58^{\mathrm{a}} \\
\pm 16.1\end{array}$ & $\begin{array}{l}50.3 \\
\pm 0.63\end{array}$ & $\begin{array}{l}430^{\mathrm{a}} \\
\pm 79.6\end{array}$ \\
\hline $\begin{array}{c}\text { Dose II } \\
2 \text { larvae/g BW }\end{array}$ & $\begin{array}{l}53.6 \\
\pm 0.84\end{array}$ & $\begin{array}{l}1379^{\mathrm{a}} \\
\pm 231.4\end{array}$ & $\begin{array}{l}28.8 \\
\pm 0.81\end{array}$ & $\begin{array}{l}344^{\mathrm{a}, \mathrm{b}} \\
\pm 105.3\end{array}$ & $\begin{array}{l}38.2 \\
\pm 0.90\end{array}$ & $\begin{array}{c}634^{\mathrm{a}} \\
\pm 136.2\end{array}$ & $\begin{array}{l}31.5 \\
\pm 0.46\end{array}$ & $\begin{array}{l}64^{\mathrm{a}} \\
\pm 11.7\end{array}$ & $\begin{array}{l}48.2 \\
\pm 0.84\end{array}$ & $\begin{array}{l}514^{\mathrm{a}} \\
\pm 63.0\end{array}$ \\
\hline $\begin{array}{c}\text { Dose III } \\
4 \text { larvae/g BW }\end{array}$ & $\begin{array}{c}51.4 \pm \\
1.06\end{array}$ & $\begin{array}{c}2542^{\mathrm{b}} \pm \\
479.0\end{array}$ & $\begin{array}{c}30.1 \pm \\
0.90\end{array}$ & $\begin{array}{c}614^{\mathrm{b}} \pm \\
121.0\end{array}$ & $\begin{array}{c}38.9 \pm \\
0.93\end{array}$ & $\begin{array}{c}1105^{\mathrm{b}} \pm \\
147.7\end{array}$ & $\begin{array}{c}31.0 \pm \\
0.68\end{array}$ & $\begin{array}{c}131^{\mathrm{b}} \pm \\
22.5\end{array}$ & $\begin{array}{c}49.3 \pm \\
0.79\end{array}$ & $\begin{array}{c}1297^{\mathrm{b}} \pm \\
143.0\end{array}$ \\
\hline
\end{tabular}

Data are expressed as mean $\pm \mathrm{SEM} ;{ }^{*}$ Body weight (BW), g, at the beginning of the experiment; ${ }^{\#}$ Larval load (rLL) was measured in the tongue, a preferred site of encystment in mice. Differences among doses, within genotype, in relative larval load were evaluated by an analysis of variance, using the Bonferroni post-test for comparisons between groups. Groups not sharing the same superscript differ significantly $(\mathrm{P}<0.01)$. 
Table 2. Effect of the host genotype on $T$. spiralis reproductive capacity index ( $\mathrm{n}=10$ per group).

\begin{tabular}{|c|c|c|c|c|c|c|c|c|c|c|}
\hline \multirow{2}{*}{$\begin{array}{l}\text { Lines } \\
\text { doses }\end{array}$} & \multicolumn{2}{|c|}{$\mathrm{CBi}+$} & \multicolumn{2}{|c|}{$\mathrm{CBi}^{-}$} & \multicolumn{2}{|c|}{$\mathrm{CBi}$} & \multicolumn{2}{|c|}{$\mathrm{CBi} / \mathrm{L}$} & \multicolumn{2}{|c|}{$\mathrm{CBi} / \mathrm{C}$} \\
\hline & $\begin{array}{l}\text { Mean } \\
\text { dose* }\end{array}$ & $\mathrm{RCI}^{\#}$ & $\begin{array}{r}\text { Mean } \\
\text { dose }\end{array}$ & $\mathrm{RCI}$ & $\begin{array}{c}\text { Mean } \\
\text { dose }\end{array}$ & $\mathrm{RCI}$ & $\begin{array}{c}\text { Mean } \\
\text { dose }\end{array}$ & RCI & Mean dose & $\mathrm{RCI}^{\#}$ \\
\hline $\begin{array}{c}\text { Dose I } \\
1 \text { larvae/g BW }\end{array}$ & 52 & $\begin{array}{l}13.4^{\mathrm{a}} \\
\pm 2.38\end{array}$ & 29 & $\begin{array}{l}2.7^{\mathrm{a}} \\
\pm 0.79\end{array}$ & 39 & $\begin{array}{l}11.9^{\mathrm{a}} \\
\pm 2.37\end{array}$ & 31 & $\begin{array}{l}2.2^{\mathrm{a}} \\
\pm 0.62\end{array}$ & 52 & $\begin{array}{l}13.4^{\mathrm{a}} \\
\pm 2.38\end{array}$ \\
\hline $\begin{array}{c}\text { Dose II } \\
2 \text { larvae/g BW }\end{array}$ & 108 & $\begin{array}{l}13.4^{\mathrm{a}} \\
\pm 2.18\end{array}$ & 58 & $\begin{array}{l}6.4^{\mathrm{a}} \\
\pm 2.08\end{array}$ & 76 & $\begin{array}{l}8.8^{\mathrm{a}} \\
\pm 1.97\end{array}$ & 63 & $\begin{array}{l}1.1^{\mathrm{a}} \\
\pm 0.19\end{array}$ & 108 & $\begin{array}{l}13.4^{\mathrm{a}} \\
\pm 2.18\end{array}$ \\
\hline $\begin{array}{c}\text { Dose III } \\
4 \text { larvae/g BW }\end{array}$ & 206 & $\begin{array}{l}12.8^{\mathrm{a}} \\
\pm 2.30\end{array}$ & 120 & $\begin{array}{l}5.6^{\mathrm{a}} \\
\pm 1.11\end{array}$ & 156 & $\begin{array}{l}7.1^{\mathrm{a}} \\
\pm 0.89\end{array}$ & 124 & $\begin{array}{l}1.1^{\mathrm{a}} \\
\pm 0.17\end{array}$ & 206 & $\begin{array}{l}12.8^{\mathrm{a}} \\
\pm 2.30\end{array}$ \\
\hline
\end{tabular}

"Mean dose for the genotype: mean number of L1 infective larvae given orally to each mouse; ${ }^{*}$ Reproductive capacity index (RCI) data are expressed as mean \pm SEM; Differences among doses, within genotype, in RCI were evaluated by an analysis of variance, using the Bonferroni post-test for comparisons between groups. Groups not sharing the same superscript differ significantly $(\mathrm{P}<0.05)$.

Table 3. Effect of the host genotype on T. spiralis infective efficiency during the intestinal phase of the infection $(\mathrm{n}=12$ per group).

\begin{tabular}{|c|c|c|c|c|c|c|c|c|c|c|}
\hline \multirow{2}{*}{$\begin{array}{c}\text { Lines } \\
\text { variables }\end{array}$} & \multicolumn{2}{|c|}{$\mathrm{CBi}^{+}$} & \multicolumn{2}{|c|}{$\mathrm{CBi}^{-}$} & \multicolumn{2}{|c|}{$\mathrm{CBi}$} & \multicolumn{2}{|c|}{$\mathrm{CBi} / \mathrm{L}$} & \multicolumn{2}{|c|}{$\mathrm{CBi} / \mathrm{C}$} \\
\hline & Day 6 & Day 13 & Day 6 & Day 13 & Day 6 & Day 13 & Day 6 & Day 13 & Day 6 & Day 13 \\
\hline $\mathrm{nPA}^{*}$ & $\begin{array}{c}9.0^{\mathrm{a}} \\
(0-48)\end{array}$ & $\begin{array}{c}6.0^{\mathrm{a}} \\
(0-30)\end{array}$ & $\begin{array}{c}7.5^{\mathrm{a}} \\
(0-18)\end{array}$ & $\begin{array}{c}6.5^{\mathrm{a}} \\
(0-17)\end{array}$ & $\begin{array}{c}10.5^{\mathrm{a}} \\
(3-24)\end{array}$ & $\begin{array}{c}8.0^{\mathrm{a}} \\
(2-20)\end{array}$ & $\begin{array}{c}13.0^{\mathrm{a}} \\
(0-23)\end{array}$ & $\begin{array}{c}0.5^{\mathrm{b}} \\
(0-4)\end{array}$ & $\begin{array}{c}11.0^{\mathrm{a}} \\
(2-23)\end{array}$ & $\begin{array}{c}4.5^{\mathrm{b}} \\
(0-13)\end{array}$ \\
\hline $\mathrm{rnPA}^{\#}$ & $\begin{array}{c}0.12^{\mathrm{a}} \\
\pm 0.042\end{array}$ & $\begin{array}{c}0.10^{\mathrm{a}} \\
\pm 0.031\end{array}$ & $\begin{array}{c}0.15^{\mathrm{a}} \\
\pm 0.028\end{array}$ & $\begin{array}{l}0.09^{\mathrm{a}} \\
\pm 0.028\end{array}$ & $\begin{array}{l}0.18^{\mathrm{a}} \\
\pm 0.026\end{array}$ & $\begin{array}{l}0.12^{\mathrm{a}} \\
\pm 0.021\end{array}$ & $\begin{array}{c}0.19^{\mathrm{a}} \\
\pm 0.033\end{array}$ & $\begin{array}{l}0.02^{\mathrm{b}} \\
\pm 0.006\end{array}$ & $\begin{array}{c}0.11^{\mathrm{a}} \\
\pm 0.022\end{array}$ & $\begin{array}{l}0.06^{\mathrm{b}} \\
\pm 0.016\end{array}$ \\
\hline $\begin{array}{l}\% \text { of mice with } \\
\text { intestinal } \\
\text { parasites }\end{array}$ & $82^{\mathrm{a}}$ & $80^{\mathrm{a}}$ & $86^{\mathrm{a}}$ & $71^{\mathrm{a}}$ & $100^{\mathrm{a}}$ & $100^{\mathrm{a}}$ & $95^{\mathrm{a}}$ & $40^{\mathrm{b}}$ & $89^{\mathrm{a}}$ & $94^{\mathrm{a}}$ \\
\hline T. spiralis $\mathrm{Ff}^{\#}$ & $\begin{array}{l}36.2^{\mathrm{a}} \\
\pm 3.14\end{array}$ & $\begin{array}{l}46.5^{\mathrm{a}} \\
\pm 4.78\end{array}$ & $\begin{array}{l}53.2^{\mathrm{a}} \\
\pm 5.82\end{array}$ & $\begin{array}{l}74.3^{\mathrm{a}} \\
\pm 9.13\end{array}$ & $\begin{array}{l}49.0^{\mathrm{a}} \\
\pm 5.95\end{array}$ & $\begin{array}{l}57.5^{\mathrm{a}} \\
\pm 6.32\end{array}$ & $\begin{array}{l}44.0^{\mathrm{a}} \\
\pm 4.29\end{array}$ & $\begin{array}{l}23.5^{\mathrm{b}} \\
\pm 3.57\end{array}$ & $\begin{array}{l}38.9^{\mathrm{a}} \\
\pm 3.72\end{array}$ & $\begin{array}{l}53.6^{\mathrm{a}} \\
\pm 9.56\end{array}$ \\
\hline
\end{tabular}

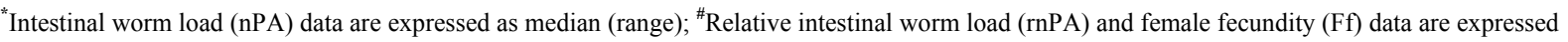
as mean \pm SEM; Differences between days post-infection within genotype were evaluated with Man-Whitney's "U" (intestinal worm load), Student's " $t$ " (relative worm load, female fecundity) or Fisher (proportion of mice with parasites) tests. For each variable, days post-infection not sharing the same superscript are significantly different at the 0.01 level.

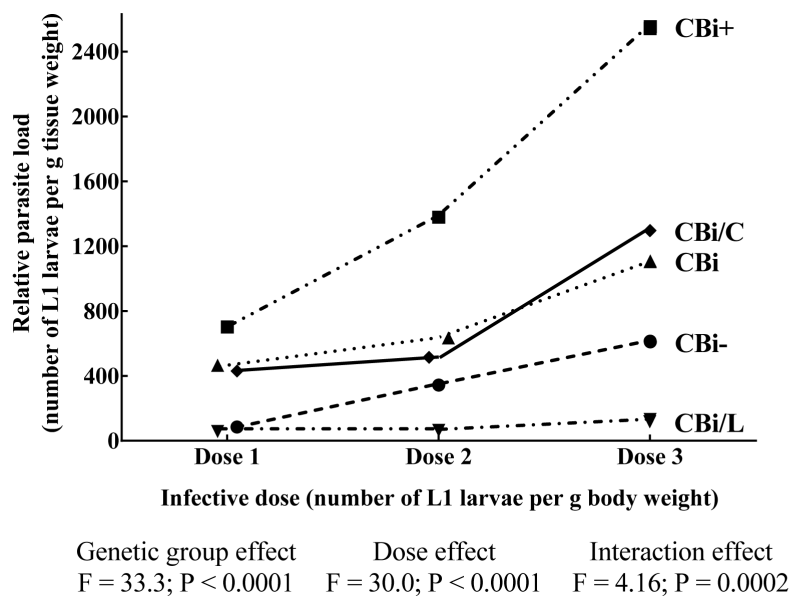

(a)

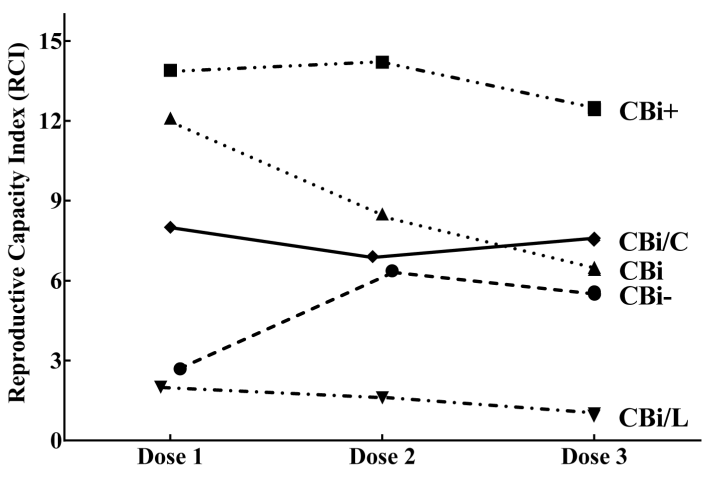

Infective dose (number of L1 larvae per g body weight)

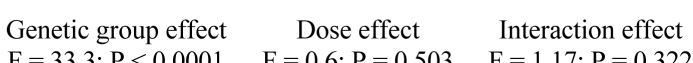

(b)

Figure 1. Effect of host genotype and dose on relative muscle larval load (a) and $T$. spiralis reproductive capacity index (b), measured on day 40 post-infection. Dose 1: $1 \mathrm{Ll}$ larvae/g BW; dose 2: $2 \mathrm{~L} 1$ larvae/g BW; dose 3: 4 L1 larvae/g BW. Each point represents the mean value of the genotype $(n=10)$ for that dose. The interaction effect was analyzed with an ANOVA corresponding to a $5 \times 3$ factorial design. 
small intestine. At day six p-i, nAP and rnAP were similar among lines $(\mathrm{P}>0.05)$. Both variables showed significant differences among genotypes at day $13(\mathrm{P}=0.0087)$. Both $\mathrm{CBi} / \mathrm{L}$ and $\mathrm{CBi} / \mathrm{C}$ had significantly reduced worm intestinal burden at day 13 compared with day six $\mathrm{p}-\mathrm{i}(\mathrm{P}<0.002)$. Also, $\mathrm{CBi} / \mathrm{L}$ mice showed a significant decrease in the proportion of mice carrying intestinal worms $(\mathrm{P}=0.0004)$, indicating that the expulsion of $T$. spiralis is markedly accelerated in this line. On the contrary, neither nAP nor rnAP showed a significant reduction by day 13 in $\mathrm{CBi}+, \mathrm{CBi}-$ and $\mathrm{CBi}$ mice. These lines and line $\mathrm{CBi} / \mathrm{C}$ did not decrease the proportion of mice positive for the parasite $(\mathrm{P}>0.05)$. Female adult worms obtained at day six p-i showed a similar fecundity in vitro (Ff) that was not influenced by the host genotype $(\mathrm{P}>0.05)$. At day $13 \mathrm{p}-\mathrm{i}$, female fecundity significantly decreased in the resistant line $(\mathrm{P}=0.017)$ and did not change in the susceptible and intermediate ones. The observed differences in muscle parasite load (rLL) in the five lines could be partly explained by the response of each genotype in the intestinal phase of infection.

Table 4 shows the serum levels of IFN- $\gamma$, IL-2, IL-4 and IL-10 that estimate the Th1/Th2 status of each line at the beginning of infection and reflect the local conditions at the site of infection [19]. A distinct serum profile was observed between $\mathrm{CBi}+$ (susceptible) and $\mathrm{CBi} / \mathrm{L}$ (resistant). $\mathrm{CBi} / \mathrm{L}$ had higher levels of $\mathrm{IL}-2(\mathrm{P}=0.023)$ and IFN- $\gamma(\mathrm{P}=0.0021)$ compared with $\mathrm{CBi}+$ whereas no significant differences for IL-4 were observed. IL-10 showed a difference with marginal significance between $\mathrm{CBi} / \mathrm{L}$ and $\mathrm{CBi}+(\mathrm{P}=0.064)$. Lines $\mathrm{CBi}^{-}, \mathrm{CBi}$ and $\mathrm{CBi} / \mathrm{C}$ had interleukins levels similar to those of $\mathrm{CBi}+$.

The principal component analysis allowed the simultaneous study of the four values of the serum interleukins determined in each mouse to find out whether there was a significant clustering of animals according to the genetic group they belong to. Table 5 contains the results of this multivariate analysis. The first two principal components accounted for $66.5 \%$ of the phenotypic variation in serum interleukin levels of which $40.3 \%$ correspond to PC1 and 26.2\% to PC2. As shown by Pearson's correlation coefficients in Table 5, PC1 values had a negative significant association with IL-4 and IL-10 levels (the higher the value of PC1, the lower the value of IL-4 and IL-10). Conversely, PC2 correlated positively and significantly with IL-2 and IFN- $\gamma$ (the higher the value of PC2, the higher the values of IL-2 and IFN- $\gamma$ ). Although non statistical significant differences were observed for PC1 mean values among lines, the extreme values corresponded to $\mathrm{CBi}+$ (negative) and $\mathrm{CBi} / \mathrm{L}$ (positive) mice. On the contrary, a significant genotype effect was evident between the same two lines on PC2 mean values. Once again $\mathrm{CBi}+$ showed the lowest (negative) value and $\mathrm{CBi} / \mathrm{L}$ the highest (positive) one. As depicted in Figure $2, \mathrm{CBi} / \mathrm{L}$ and $\mathrm{CBi}+$, which have a differential response against infection with $T$. spiralis, also showed a different and opposite combination of interleukins before being infected with the parasite.

Table 4. Serum interleukin levels ${ }^{*}$ in adult mice of the CBi-IGE stock before infection with T. spiralis L1 larvae ( $\mathrm{n}=7$ per group).

\begin{tabular}{cccccc}
\hline $\begin{array}{c}\text { Lines } \\
\text { interleukines }\end{array}$ & $\mathrm{CBi}+$ & $\mathrm{CBi}-$ & $\mathrm{CBi}$ & $\mathrm{CBi} / \mathrm{L}$ & $\mathrm{CBi} / \mathrm{C}$ \\
\hline IL-2 & $4.6 \pm 0.16^{\mathrm{a} \#}$ & $4.9 \pm 0.25^{\mathrm{a}}$ & $6.5 \pm 0.73^{\mathrm{a}, \mathrm{b}}$ & $9.5 \pm 2.01^{\mathrm{b}}$ & $5.1 \pm 0.26^{\mathrm{a}}$ \\
IFN- $\gamma$ & $35.8 \pm 3.88^{\mathrm{a}}$ & $55.9 \pm 6.47^{\mathrm{a}, \mathrm{b}}$ & $50.3 \pm 4.32^{\mathrm{a}, \mathrm{b}}$ & $63.3 \pm 7.72^{\mathrm{b}}$ & $54.6 \pm 6.20^{\mathrm{a}, \mathrm{b}}$ \\
IL-4 & $17.6 \pm 2.58^{\mathrm{a}}$ & $13.9 \pm 1.63^{\mathrm{a}}$ & $19.1 \pm 2.45^{\mathrm{a}}$ & $14.3 \pm 2.45^{\mathrm{a}}$ & $16.1 \pm 2.12^{\mathrm{a}}$ \\
IL-10 & $41.2 \pm 5.32^{\mathrm{a}}$ & $33.7 \pm 4.74^{\mathrm{a}}$ & $46.8 \pm 5.57^{\mathrm{a}}$ & $29.2 \pm 2.51^{\mathrm{a}}$ & $46.8 \pm 7.17^{\mathrm{a}}$ \\
\hline
\end{tabular}

${ }^{*} \mathrm{pg} / \mathrm{ml}$; "Data are expressed as mean \pm SEM; Differences among genotypes in serum cytokine levels were evaluated by an analysis of variance, using the Bonferroni post-test for comparisons between groups. Groups not sharing the same superscript differ significantly (P $<0.01)$.

Table 5. First and second principal components values in adult mice of the CBi-IGE stock and Pearson product-moment correlation coefficient between serum interleukin level and principal component value.

\begin{tabular}{|c|c|c|c|c|c|c|c|c|c|}
\hline & \multicolumn{5}{|c|}{ Lines } & \multicolumn{4}{|c|}{ Pearson's correlation coefficient (r) } \\
\hline & $\mathrm{CBi}+$ & $\mathrm{CBi} / \mathrm{C}$ & $\mathrm{CBi}$ & $\mathrm{CBi} / \mathrm{L}$ & $\mathrm{CBi}-$ & IL-2 & IL-4 & IL-10 & IFN- $\gamma$ \\
\hline $\mathrm{PC} 1$ & $\begin{array}{l}-0.574^{\text {aft }} \\
\pm 0.4528\end{array}$ & $\begin{array}{c}-0.303^{\mathrm{a}} \\
\pm 0.5836\end{array}$ & $\begin{array}{l}-0.488^{\mathrm{a}} \\
\pm 0.3683\end{array}$ & $\begin{array}{c}1.120^{\mathrm{a}} \\
\pm 0.2775\end{array}$ & $\begin{array}{c}0.673^{\mathrm{a}} \\
\pm 0.1096\end{array}$ & $\begin{array}{c}0.282 \\
\mathrm{P}=0.117\end{array}$ & $\begin{array}{c}-0.811 \\
\mathrm{P}<0.0001\end{array}$ & $\begin{array}{c}-0.851 \\
\mathrm{P}<0.0001\end{array}$ & $\begin{array}{c}0.386 \\
\mathrm{P}=0.029\end{array}$ \\
\hline $\mathrm{PC} 2$ & $\begin{array}{l}-0.998^{\mathrm{a}} \\
\pm 0.3289\end{array}$ & $\begin{array}{l}-0.228^{\mathrm{a}, \mathrm{b}} \\
\pm 0.1247\end{array}$ & $\begin{array}{l}-0.249^{\mathrm{a}, \mathrm{b}} \\
\pm 0.3378\end{array}$ & $\begin{array}{c}0.921^{\mathrm{b}} \\
\pm 0.4663\end{array}$ & $\begin{array}{l}-0.087^{\mathrm{a}, \mathrm{b}} \\
\pm 0.2801\end{array}$ & $\begin{array}{c}0.721 \\
\mathrm{P}<0.0001\end{array}$ & $\begin{array}{c}0.305 \\
\mathrm{P}=0.089\end{array}$ & $\begin{array}{c}0.152 \\
\mathrm{P}=0.395\end{array}$ & $\begin{array}{c}0.672 \\
\mathrm{P}<0.0001\end{array}$ \\
\hline
\end{tabular}

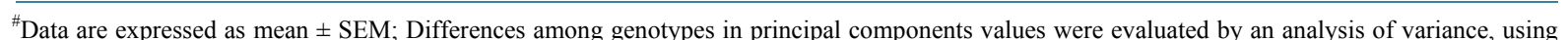
the Bonferroni post-test for comparisons between groups. Groups not sharing the same superscript differ significantly $(\mathrm{P}<0.05)$. 


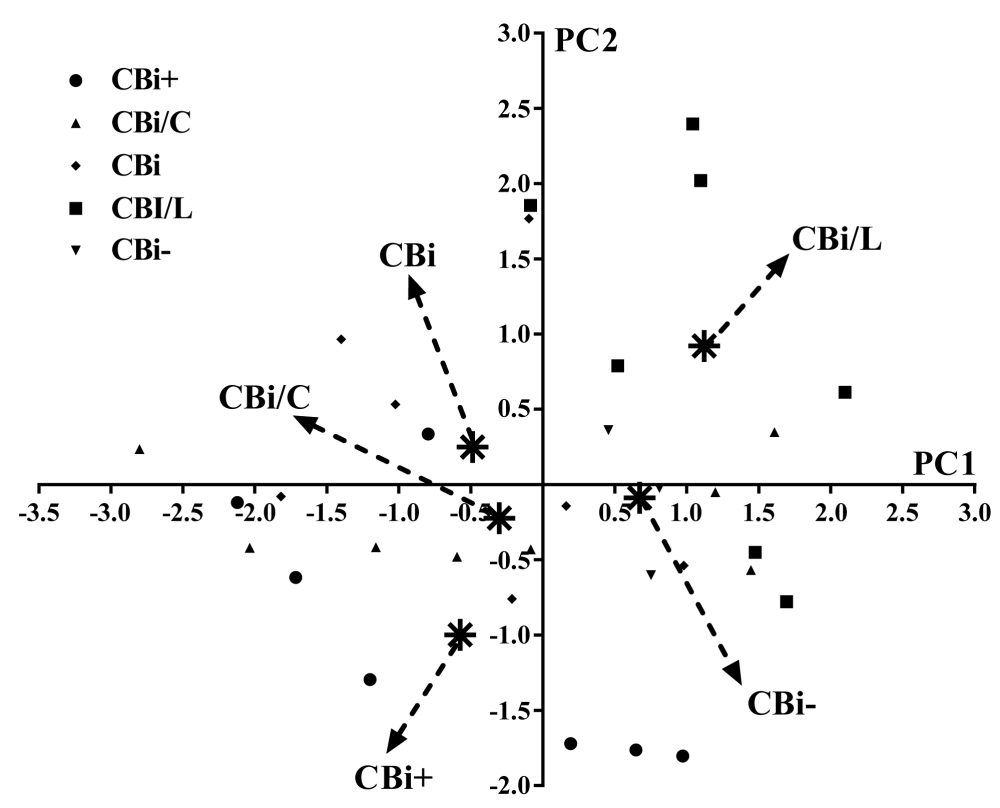

Figure 2. Scatterplot showing the location of the five genetic groups in a Cartesian coordinate system of the first two principal components ( $\rho$ represents the mean value of PC1 and PC2 for each genotype). It should be noted that naive $\mathrm{CBi}+$ mice showed a predominant $\mathrm{Th} 2$ profile (lower-left quadrant: high IL-4 and Il-10, low IL-2 and IFN- $\gamma$ ) while that of $\mathrm{CBi} / \mathrm{L}$ mice was a Th1 one (upperright quadrant: low IL-4 and IL-10, high IL-2 and IFN- $\gamma$ ).

\section{Discussion}

Parasites, including helminths, are currently responsible for more morbidity and mortality than any other type of infectious organism. Trichinella spiralis, the causative agent of trichinellosis, is characterized by occupying two distinct intracellular niches within its host, the intestinal epithelium and the skeletal muscle. The complicated life cycle of the parasite, coupled with its varied ecological niches and morphological forms, elicits a complex range of sophisticated host defense mechanisms to resist invasion. This response for resisting parasitic diseases is under genetic control and varies among species and individuals within species. In this context, mice have played an important role in elucidating the molecular pathways that contribute to disease. Well-defined inbred mouse lines, among other approaches, are valuable tools for dissecting the effects of host genes in complex traits [20] such as infectious diseases. The phenotypically distinct lines that make up the CBi-IGE colony are the result of experiments of long-term divergent selection held for more than 120 generations. These lines are a unique resource for dissecting the genetic basis underlying line divergence since they may help expose genes causing variation in unselected mouse populations and, via sequence homology, in other species including humans. The genetic differences exhibited between mouse strains most likely control or contribute to a wide range of processes that influence the outcome of a parasitic infection [21]. Differences between host strain backgrounds in their responses to infection have previously been demonstrated in a variety of infection models, including the nematodes Trichuris muris [22], Heligmosomoides polygyrus [23] and the protozoan Leishmania major [24], where host background leads to variation in susceptibility to these chronic infections.

The resistance/susceptibility of a host against $T$. spiralis is defined by the number of parasites encysted in muscle in the chronic phase of infection; this number represents the result of the cumulative effects of all antiparasite responses expressed by the host [25]. In the range of doses studied, a genotype-dose interaction was observed in muscle parasite load since the same dose increase did not produce the same increase in muscle load in the five genotypes. $\mathrm{CBi}-$ and $\mathrm{CBi} / \mathrm{L}$ mice were resistant at the lowest dose while $\mathrm{CBi}+, \mathrm{CBi} / \mathrm{C}$, and $\mathrm{CBi}$ were susceptible. At the highest dose only $\mathrm{CBi} / \mathrm{L}$ continued being resistant, $\mathrm{CBi}+$ and $\mathrm{CBi} / \mathrm{C}$ were the most susceptible while $\mathrm{CBi}$ and $\mathrm{CBi}-$ had an intermediate response. At variance with other investigators [10] [26]-[29], the infective doses given to mice in this study were relatively low. This dosage would explain the lack of signs and symptoms of trichinellosis in mice in the period studied, as well as the responses observed both at the intestinal 
and muscle stage of infection.

A common biological characteristic used to evaluate Trichinella spp infectivity is the index of reproductive capacity (RCI) defined as the ratio of the total number of muscle larvae recovered from an animal to the number of larvae administered to it. RCI can be disaggregated in four components: the number of females established; their fecundity; their reproductive life span and the survival of larvae in muscles [16]. The reproductive capacity index showed only effect of genotype, so this variable allowed qualifying each genotype as resistant or susceptible regardless of dose. As derived from the analysis of $\mathrm{RCI}, \mathrm{CBi}+$ was the most susceptible genotype and $\mathrm{CBi} / \mathrm{L}$ the most resistant, $\mathrm{CBi}, \mathrm{CBi} / \mathrm{C}$ and $\mathrm{CBi}-$ being intermediate. It should be noted that except in line $\mathrm{CBi}^{-}$, mice tended to be more susceptible to the lowest dose, a characteristic reported for humans in which exposure to low doses was associated with a considerable risk of infection [30].

The host immune response against a parasite is a remarkable phenomenon in the pathology of infection and control of the parasite population. Multiple immune and non-immune effector mechanisms limit the number of larvae surviving migration to host tissues. Previous studies have shown that host immunity regulates the fecundity of nematodes [31] [32] as well as worm expulsion [33]-[35] and that host genetics determines T. spiralis rejection from the intestine in mice [36] [26]. Thus, evaluating both the rate of parasite expulsion and female parasite fecundity provides greater insight into the underlying causes of increased larval burdens in animals exposed to a challenge infection. Results of these assays can be compared to results of cellular, humoral or innate immune function assays [9]. This response against invading pathogens is mediated by mechanisms that result from the combined action of several genes, which are not fully known. In this experimental model, the results of the variables analyzed in the acute stage of infection could explain part of the host susceptibility. The complex life cycle of this nematode that also induces a profound modulation on the expression of the host's genes would be one of the causes of the diverse host response. The response of each genotype during the enteric phase of infection was assessed in mice infected with two L1 $T$. spiralis larvae per g body weight, by measuring intestinal parasite load (nAP, total number of adult parasites) and fecundity of $T$. spiralis females (Ff, average number of newborn larvae per female parasite). At variance with other reports [37], a significant phenotypic variation was evident among strains at this dose. $\mathrm{CBi} / \mathrm{L}$ had expelled almost all its intestinal worms by day 13 , whereas $\mathrm{CBi} / \mathrm{C}$ reduced to half its intestinal parasite load and $\mathrm{CBi}^{+}, \mathrm{CBi}^{-}$, and $\mathrm{CBi}$ showed no significant expulsion at this time point. A decrease $(\mathrm{P}<0.01)$ in $\mathrm{nAP}$, in the proportion of mice with $T$. spiralis intestinal worms and $\mathrm{Ff}$ between 6 and 13 days post-infection in $\mathrm{CBi} / \mathrm{L}$ would be the result of an early immune response generating an unsuitable environment for the establishment of intestinal adult parasites and an improved trapping of newborn larvae in the lungs [38]. nAP decreased in $\mathrm{CBi}^{-}, \mathrm{CBi}^{+}, \mathrm{CBi} / \mathrm{C}$ and $\mathrm{CBi}$, during this period $(\mathrm{P}<0.01)$, however the proportion of mice with $T$. spiralis worms and $\mathrm{Ff}$ did not change $(\mathrm{P}>0.05)$. This response could be due to an immune response that would facilitate the parasite to complete its life cycle.

Resistance to nematodes is a physiological and genetically complex character difficult to measure. Parasites such as helminths have acquired the ability to attenuate the immune response of the host, protecting themselves from expulsion and minimizing the pathology in the host, to ensure their survival and achieve chronicity. A major global health challenge, for this reason, is to understand how parasites manipulate the finely balanced homeostatic system of host defense in order to establish a long-term infection. As stated by Gause et al. [39], helminth infections are characterized by their ability to induce Th2-cell responses that generally result in eosinophilia, goblet and mucosal mast-cell hyperplasia and the production of non-complement fixing antibodies. However, despite these general common trends, it is becoming increasingly clear that the immune response differs considerably between different helminths. $T$. spiralis induces a mixed cytokine response probably because the presence of these parasites within host cells triggers IFN- $\gamma$ production in a manner similar to that required for host defense against many intracellular pathogens [33]. Each stage of the life cycle of $T$. spiralis can evoke a stage-specific host immune response since parasite antigens are unique to each stage. Even so, given the speed with which the life cycle of this nematode develops, a host mounting an adequate protective immune response during primary infection fails to rid completely of the parasite. For $T$. spiralis, the intestine is the first host organ to be parasitized and to elicit an immune response. It is believed that a Th1-type cytokine response occurs during the first hours of infection and, shortly after, a Th2-type response begins to dominate, usually protecting the host against a chronic infection. The combination of interleukins observed in naïve $\mathrm{CBi} / \mathrm{L}$, skewed to Th1, may better prepare these mice to the initial "default" Th1 response to invasion [40], since it has been reported that, within 2 days of worms reaching the intestine, mesenteric lymph nodes cells respond with a Th1 rather than a Th2 response [27]. The level of infectivity of $T$. spiralis is linked to the number of newborn larvae that manage to 
reach the general circulation and encyst in muscles. Therefore, the resistance to this infection is related to the ability of the host to generate a response that prevents the development of infective larvae, removing adult worms from the small intestine, limiting the fertility of adult females, and destroying newborn larvae. The observed differences in the degree of infection with increasing doses was partly the result of differences in resistance mechanisms, determined by the genetics of the host, as could be assessed by the variables measured in the enteral stage of the infection. During primary infection, the combination of immunological players is determined by the host and modulated by the parasite, and may lead to a high degree of infection (susceptibility) or to the development of a strong protective response that reduces the level of infection (resistance).

\section{Conclusion}

The use of animal models for biomedical research plays a critical role in understanding disease processes and developing appropriate treatments. When looking to extrapolate results of animal species to man, it is necessary that the biological model reproduce, as accurately as possible, the effects of the original condition. The results described herein suggest that the genetic analysis of the CBi-IGE model will be useful to further analyze the mechanisms that control the complex and dynamic relationship between parasite and host, as mouse genetics differs little from human and T. spiralis is a natural parasite of this animal species. The establishment and growth of parasites not only depend on the infective dose and the "entrance door", but also require overcoming a number of barriers that the host presents. After facing the host physiological conditions and immune response, the parasite seeks to bring the infection to chronicity. The mechanisms involved are not fully elucidated due to the complexity of the interactions among host, parasite and environment. The variability in the response observed in this model suggests its potential usefulness to clarify the mechanisms that regulate the multifaceted and dynamic relationship between host and parasite. This knowledge is essential to progress in the control of parasitic diseases based on the genetic resistance of the host.

\section{Acknowledgements}

A.V.C. is grateful to CIUNR (Consejo de Investigaciones, Universidad Nacional de Rosario) for a Research Fellowship.

\section{Funding}

This work was supported by Universidad Nacional de Rosario (Res. C.S. 216/2012-and 081/2014) and by Fundación Alberto J. Roemmers (2009-2010). None of these funding institutions was involved in the study design, collection, analysis and interpretation of data, writing of the report, and decision to submit the article for publication.

\section{Transparency Declarations}

None to declare.

\section{References}

[1] Calcagno, M.A., Teixeira, C., Forastiero, M.A., Costantino, S.N. and Venturiello, S.M. (2005) Clinical, Serological and Parasitological Aspects of an Outbreak of Human Trichinellosis in Villa Mercedes, San Luis, Argentina. The Acute and Chronic Phases of the Infection. Medicina, 65, 302-306.

[2] Gottstein, B., Pozio, E. and Nöckler, K. (2009) Epidemiology, Diagnosis, Treatment, and Control of Trichinellosis. Clinical Microbiology Reviews, 22, 127-145. http://dx.doi.org/10.1128/CMR.00026-08

[3] Artis, D. (2006) New Weapons in the War on Worms: Identification of Putative Mechanisms of Immune-Mediated Expulsion of Gastrointestinal Nematodes. International Journal for Parasitology, 36, 723-733. http://dx.doi.org/10.1016/j.ijpara.2006.02.011

[4] Vasconi, M.D., Malfante, P., Bassi, A., Giudici, C., Revelli, S., Di Masso, R., Font, M.T. and Hinrichsen, L. (2008) Phenotypic Differences on the Outcome of the Host-Parasite Relationship: Behavior of Mice of the CBi Stock in Natural and Experimental Infections. Veterinary Parasitology, 153, 157-163. http://dx.doi.org/10.1016/j.vetpar.2008.01.019

[5] Gray, G.D. and Gill, H.S. (1993) Host Genes, Parasites and Parasitic Infections. International Journal for Parasitology, 


\section{3, 485-494. http://dx.doi.org/10.1016/0020-7519(93)90037-Y}

[6] Di Masso, R.J., Abdala, S., Sanchez, S.M. and Font, M.T. (1991) Respuesta a la selección divergente por conformación corporal en el ratón. Mendeliana, 9, 79-92.

[7] Hinrichsen, L.I. and Di Masso, R.J. (2010) Use of a Murine Model Original of Argentina to Characterize Complex Phenotypes. Journal of Basic and Applied Genetics, 21, 1-12.

[8] Guide for the Care and Use of Laboratory Animals (2011) National Research Council. 8th Edition, The National Academies Press, Washington DC.

[9] Luebke, R.W. (2007) Nematodes as Host Resistance Models for Detection of Immunotoxicity. Methods, 41, 38-47. http://dx.doi.org/10.1016/j.ymeth.2006.06.016

[10] Perrudet-Badoux, A., Binaghi, R.A. and Biozzi, G. (1975) Trichinella Infestation in Mice Genetically Selected for High and Low Antibody Production. Immunology, 29, 387-390.

[11] Perrudet-Badoux, A., Binaghi, R.A. and Boussac-Aron, Y. (1978) Trichinella spiralis Infection in Mice. Mechanism of the Resistance in Animals Genetically Selected for High and Low Antibody Production. Immunology, 35, 519-522.

[12] Reiterová, K., Antolová, D. and Hurníková, Z. (2009) Humoral Immune Response of Mice Infected with Low Doses of Trichinella spiralis Muscle Larvae. Veterinary Parasitology, 159, 232-235. http://dx.doi.org/10.1016/j.vetpar.2008.10.048

[13] Martínez-Gómez, F., Fuentes-Castro, B.E. and Bautista-Garfias, C.R. (2011) The Intraperitoneal Inoculation of Lactobacillus casei in Mice Induces Total Protection against Trichinella spiralis Infection at Low Challenge Doses. Parasitology Research, 109, 1609-1617. http://dx.doi.org/10.1007/s00436-011-2432-2

[14] Leclair, D., Forbes, L.B., Suppa, S. and Gajadhar, A.A. (2003) Evaluation of a Digestion Assay and Determination of Sample Size and Tissue for the Reliable Detection of Trichinella Larvae in Walrus Meat. Journal of Veterinary Diagnostic Investigation, 15,188-191. http://dx.doi.org/10.1177/104063870301500217

[15] Kapel, C.M.O. and Gamble, H.R. (2000) Infectivity, Persistence, and Antibody Response to Domestic and Sylvatic Trichinella spp. in Experimentally Infected Pigs. International Journal for Parasitology, 30, 215-221. http://dx.doi.org/10.1016/S0020-7519(99)00202-7

[16] Dvorožňáková, E., Hurníková, Z. and Kołodziej-Sobocińska, M. (2011) Development of Cellular Immune Response of Mice to Infection with Low Doses of Trichinella spiralis, Trichinella britovi and Trichinella pseudospiralis Larvae. Parasitology Research, 108, 169-176. http://dx.doi.org/10.1007/s00436-010-2049-x

[17] Sheskin, D.J. (2011) Handbook of Parametric and Non-Parametric Statistical Procedures. 5th Edition, Chapman \& Hall/CRC, London.

[18] Tatsuoka, M. (1971) Multivariate Analysis. Techniques for Educational and Psychological Research. John Wiley and Sons Inc., New York.

[19] Taylor, M.D., Betts, C.J. and Else, K.J. (2000) Peripheral Cytokine Responses to Trichuris muris Reflect Those Occurring Locally at the Site of Infection. Infection and Immunity, 68, 1815-1819. http://dx.doi.org/10.1128/IAI.68.4.1815-1819.2000

[20] Peters, L.L., Robledo, R.F., Bult, C.J., Churchill, G.A., Paigen, B.J. and Svenson, K.L. (2007) The Mouse as a Model for Human Biology: A Resource Guide for Complex Trait Analysis. Nature Reviews Genetics, 8, 58-69. http://dx.doi.org/10.1038/nrg2025

[21] Longley, R., Smith, C., Fortin, A., Berghout, J., McMorran, B., Burgio, G., Foote, S. and Gros, P. (2011) Host Resistance to Malaria: Using Mouse Models to Explore the Host Response. Mammalian Genome, 22, 32-42. http://dx.doi.org/10.1007/s00335-010-9302-6

[22] Blackwell, N.M. and Else, K.J. (2002) A Comparison of Local and Peripheral Parasite-Specific Antibody Production in Different Strains of Mice Infected with Trichuris muris. Parasite Immunology, 24, 203-211. http://dx.doi.org/10.1046/j.1365-3024.2002.00452.X

[23] Filbey, K.J., Grainger, J.R., Smith, K.A., Boon, L., van Rooijen, N., Harcus, Y., Jenkins, S., Hewitson, J.P. and Maizels, R.M. (2014) Innate and Adaptive Type 2 Immune Cell Responses in Genetically Controlled Resistance to Intestinal Helminth Infection. Immunology and Cell Biology, 92, 436-448. http://dx.doi.org/10.1038/icb.2013.109

[24] Kobets, T., Havelková, H., Grekov, I., Volkova, V., Vojtíšková, J., et al. (2012) Genetics of Host Response to Leishmania Tropica in Mice-Different Control of Skin Pathology, Chemokine Reaction, and Invasion into Spleen and Liver. PLoS Neglected Tropical Diseases, 6, e1667. http://dx.doi.org/10.1371/journal.pntd.0001667

[25] Vasilev, S., Gruden-Movsesijan, A., Ilic, N. and Sofronic-Milosavljevic, L.J. (2009) Strain Difference in Susceptibility to Trichinella spiralis Infection between Dark Agouti and Albino Oxford Rats. Veterinary Parasitology, 159, $229-231$. http://dx.doi.org/10.1016/j.vetpar.2008.10.042

[26] Bell, R.G. (1988) Genetic Analysis of Expulsion of Adult Trichinella spiralis in NFS, C3H/He, and B10.BR Mice. 
Experimental Parasitology, 66, 57-65. http://dx.doi.org/10.1016/0014-4894(88)90050-1

[27] Ishikawa, N., Goyal, P.K., Mahida, Y.R., Li, K.F. and Wakelin, D. (1998) Early Cytokine Responses during Intestinal Parasitic Infections. Immunology, 193, 257-263. http://dx.doi.org/10.1046/j.1365-2567.1998.00412.x

[28] Dehlawi, M.S. and Goyal, P.K. (2003) Responses of Inbred Mouse Strains to Infection with Intestinal Nematodes. Journal of Helminthology, 77, 119-124. http://dx.doi.org/10.1079/JOH2003175

[29] Dvorožňáková, E., Kołodziej-Sobocińska, M. and Hurníková, Z. (2012) Trichinella spiralis Reinfection: Changes in Cellular and Humoral Immune Response in BALB/c Mice. Helminthologia, 49, 201-210. http://dx.doi.org/10.2478/s11687-012-0039-5

[30] Teunis, P.F., Koningstein, M., Takumi, K. and van der Giessen, J.W. (2012) Human Beings Are Highly Susceptible to Low Doses of Trichinella spp. Epidemiology Infection, 140, 210-218. http://dx.doi.org/10.1017/S0950268811000380

[31] Marti, H.P. and Murrell, K.D. (1986) Trichinella spiralis: Antifecundity and Antinewborn Larvae Immunity in Swine. Experimental Parasitology, 62, 370-375. http://dx.doi.org/10.1016/0014-4894(86)90044-5

[32] Hashimoto, K., Uchikawa, R., Tegoshi, T., Takeda, K., Yamada, M. and Arizono, N. (2010) Immunity-Mediated Regulation of Fecundity in the Nematode Heligmosomoides polygyrus-The Potential Role of Mast Cells. Parasitology, 137, 881-887. http://dx.doi.org/10.1017/S0031182009991673

[33] Lawrence, C.E. (2003) Is There a Common Mechanism of Gastrointestinal Nematode Expulsion? Parasite Immunology, 25, 271-281. http://dx.doi.org/10.1046/j.1365-3024.2003.00630.x

[34] Maizels, R.M., Pearce, E.J., Artis, D., Yazdanbakhsh, M. and Wynn, T.A. (2009) Regulation of Pathogenesis and Immunity in Helminth Infections. Journal of Experimental Medicine, 206, 2059-2066. http://dx.doi.org/10.1084/jem.20091903

[35] Knight, P.A., Brown, J.K. and Pemberton, A.D. (2008) Innate Immune Response Mechanisms in the Intestinal Epithelium: Potential Roles for Mast Cells and Goblet Cells in the Expulsion of Adult Trichinella spiralis. Parasitology, 135, 655-670. http://dx.doi.org/10.1017/S0031182008004319

[36] Bell, R.G., Adams, L.S. and Ogden, R.W. (1984) A Single Gene Determines Rapid Expulsion of Trichinella spiralis in Mice. Infection and Immunity, 45, 273-275.

[37] Bell, R.G. and Liu, W.M. (1988) Trichinella spiralis: Quantitative Relationships between Intestinal Worm Burden, Worm Rejection, and the Measurement of Intestinal Immunity in Inbred Mice. Experimental Parasitology, 66, 44-56. http://dx.doi.org/10.1016/0014-4894(88)90049-5

[38] Gentilini, M.V., Nuñez, G.G., Roux, M.E. and Venturiello, S.M. (2011) Trichinella spiralis Infection Rapidly Induces Lung Inflammatory Response: The Lung as the Site of Helminthocytotoxic Activity. Immunobiology, 216, 1054-1063. http://dx.doi.org/10.1016/j.imbio.2011.02.002

[39] Gause, W.G., Urban Jr., J.F. and Stadecker, M.J. (2003) The Immune Response to Parasitic Helminths: Insights from Murine Models. Trends in Immunology, 24, 269-277. http://dx.doi.org/10.1016/S1471-4906(03)00101-7

[40] Hsieh, C.-S., Macatonia, S.E., O’Garra, A. and Murphy, K.M. (1995) T Cell Genetic Background Determines Default T Helper Phenotype Development in Vitro. Journal of Experimental Medicine, 181, 713-721. http://dx.doi.org/10.1084/jem.181.2.713 